DOI 10.4467/2543733XSSB.20.001.12190

JANUSZ SMOŁUCHA

Akademia Ignatianum w Krakowie

\title{
OKOLICZNOŚCI ROZPOCZECCIA W KRAKOWIE W SIERPNIU 1596 R. PERTRAKTACJI W SPRAWIE ZAWIĄZANIA PRZEZ PAPIEŻA KLEMENSA VIII ANTYTURECKIEJ LIGI ŚWIĘTEJ
}

\author{
The Background of the Negotiations Concerning \\ the Establishment of the Anti-Turkish Holy League Initiated \\ by Pope Clement VIII \\ in Krakow in August 1596
}

Summary

The article deals with the circumstances behind the negotiations in Krakow in the summer of 1596, the aim of which was to form the Holy League against Turkey under the auspices of Pope Clement VIII. Both the representatives of the Polish Sejm and Senate as well as the delegates of Emperor Rudolf II Habsburg gathered there together to discuss the matter. The Pope, on his part, sent Cardinal Enrico Caetani, elevated to the rank of legatus de latere, with the mission to preside over and facilitate the negotiations. One of the many challenges faced by the congress, which brought together a number of significant political and religious leaders, was to ease the tensions between Poland and Austria and focus their efforts on the idea of war against Turkey. In order to present the background and the course of these consultations, the authors draws extensively from both Polish and foreign primary sources, including the ones housed in the collections of the Vatican Archive and the Vatican Library. The most valuable of them is The Diary written by Paolo Mucante, who accompanied Cardinal Caetani Giovanni throughout his journey. As a keen observer, with a sharp eye for cultural, religious and political differences, Mucante left a captivating description of peoples, customs and events to posterity.

Keywords: the Holy League, the Kingdom of Poland, Papacy, Habsburgs, Ottoman Turkey, Islam, Crusades

Słowa kluczowe: Liga Święta, Królestwo Polskie, papiestwo, Habsburgowie, Turcja osmańska, islam, krucjata 
Wiosną 1596 r. papież Klemens VIII wyprawił do Polski w randze legata a latere kardynała Enrico Caetaniego z misją nakłonienia Rzeczypospolitej do przyłączenia się do Ligi Świętej, organizowanej przez Rzym przeciwko Turkom Osmańskim ${ }^{1}$. Do realizacji tego zadania, w kontekście politycznych różnic dzielących potencjalnych sojuszników, Caetani - wywodzący się ze starego rzymskiego rodu, posiadający odpowiednie kwalifikacje i niezwykle bogate doświadczenie dyplomatyczne - został wybrany nieprzypadkowo. Od 1587 r. Enrico Caetani pełnił urząd Kamerlinga Świętego Kościoła Rzymskiego, czyli kierownika Kamery Apostolskiej. Funkcja ta stawiała go w rzędzie najbardziej wpływowych i potężnych dostojników w kolegium kardynałów. W związku z tym zaczęto powierzać mu istotne z punktu widzenia Stolicy Apostolskiej zadania dyplomatyczne. W latach 1589-1590 działał m.in. jako legat a latere we Francji na rzecz wyboru katolickiego władcy po śmierci króla Henryka III $^{2}$. W hierarchii papieskiej dyplomacji legaci a latere stali na samym szczycie drabiny urzędniczej, o wiele wyżej niż nuncjusze. Ich misje w epoce nowożytnej miały ściśle określony zakres tematyczny i czasowy. Zawsze jednak odnosiły się do spraw najwyższej wagi z punktu widzenia Stolicy Apostolskiej ${ }^{3}$.

Po przyjęciu papieskiego polecenia kardynał Caetani starannie zaczął dobierać osoby, które miały mu towarzyszyć w nowej misji dyplomatycznej. Familia kardynała, z którą udał się w drogę, liczyła kilkadziesiąt osób, a w całej kawalkadzie, jak zanotowały źródła, szło łącznie 160 koni. Asystowali mu jego dwaj nepoci, Bonifazio (ur. 1568) - ówczesny gubernator Camerino i Orvieto oraz Antonio (ur. 1566), piastujący funkcję papieskiego kamerariusza. Obaj młodzieńcy pełnić mieli najbardziej poufne i wymagające zadania polityczno-dyplomatyczne. Poza wyżej wymienionymi pierwszorzędną rolę odegrać miał Bonifazio Vanozzi, sprawujący funkcję osobistego sekretarza Enrica Caetaniego. Był on odpowiedzialny za korespondencję dyplomatyczną kierowaną zarówno do Rzymu, jak i tę wysyłaną na miejscu do wysokich dygnitarzy duchownych i świeckich. W spuściźnie Vanozziego z okresu analizowanej misji dominują listy kardynała Enrico Caetaniego pisane do Sekretarza Stanu Stolicy Apostolskiej - Cinzio Passeri Aldobrandiniego, kardynała San Giorgio in Valabro, do papieża, do nuncjusza w Polsce - biskupa San Severo Germanika Malaspiny oraz do nuncjusza przy cesarzu, biskupa Cremony Cesare Speciano ${ }^{4}$.

${ }^{1}$ G. Caetani, Domus Caietana. Storia documentata della famiglia Caetani. Il Cinquecento, t. 2, Sancasciano Val di Pesa 1933, s. 300-303; Klemens VIII wyznaczył kardynała Caetaniego jako kardynała a latere do Królestwa Polskiego na konsystorzu w dniu 3 kwietnia 1596 r. Zob. J. W. Woś, Istruzione al cardinale Enrico Caetani per la sua missione in Polonia negli anni 1596-1597, „Annali della Scuola Normale Superiore di Pisa. Classe di Lettere e Filosofia”, Serie III, 6/3, 1976, s. 933.

${ }^{2}$ H. de L'Epinois, La légation du cardinal Caetani en France, ,Revue des ques tions historiques”, 30, 1881, s. 60-525; C. Manfroni, La legazione del cardinal Caetani in Francia (1589-1590), „Rivista storica italiana”, 10, 1893, s. 90-270; M. de Boûard, Sixte-Quint, Henri IV et la Ligue. La légation du cardinal Caetani en France (1589-1590), „Revue des questions historiques”, 60, 1932, s. 59-140; K. Jaitner, Die Hauptinstruktionen Clemens' VIII. für die Nuntien und Legaten an den europäischen Fürstenhofen (1592-1605), t. 1, Tübingen 1984, s. 182-184; B. Barbiche, S. De Dainville-Barbiche, Les légats ,, a latere» en France et leurs facultés aux XVI et XVII ${ }^{e}$ siècles, „Archivum Historiae Pontificiae”, 23, 1985, s. 101-161.

${ }^{3}$ B. Barbiche, S. De Dainville-Barbiche, Les légats a latere à l'epoque moderne et le personnel des légations, [w:] Bulla, Legatus, Nuntius. Études de diplomatique et de diplomatie pontificales (XIII $-X V I I^{e}$ siècle), red. B. Barbiche, Paris 2007, s. 284-293; M. F. Feldkamp, La diplomazia pontificia, Milano 1998, s. 29-36; W Rzeczypospolitej od 1592 r. działał nuncjusz Germanicus Malaspina, którego misja zakończyła się w kwietniu 1598 r.- Acta Nuntiaturae Polonae, t. XV/1, wyd. L. Jarmiński, Kraków 2000, s. XV i n.

${ }^{4}$ Kopie listów kardynała Enrico Caetaniego, sporządzone przez Bonifazia Vanoziego, przechowywane są obecnie głównie w archiwach rzymskich, m.in. Archivum Apostolicum Vaticanum (dalej AAV), Segr. Stato, 
Pewna część tych listów, po wstępnym uporządkowaniu, została wydana drukiem w 1606 r. w Wenecji ${ }^{5}$.

Najbardziej zasłużonym dla uwiecznienia opisywanej legacji kardynała Caetaniego był papieski ceremoniarz Giovanni Paolo Mucante, który wziął udział w tej misji na osobiste polecenie papieża Klemensa VIII. Ten będąc absolwentem jezuickiego Kolegium Rzymskiego, nie wstapił jednak do Towarzystwa Jezusowego, ale wybrał drogę kariery duchownej jako ceremoniarz papieski. Biorąc udział w misji dyplomatycznej Caetaniego, miał nadzorować uroczystości natury religijnej i dbać o ich prawidłowy przebieg. Pomimo jasno określonych kompetencji Mucante, prawdopodobnie z własnej inicjatywy, postanowił spisać najważniejsze wydarzenia tej legacji w formie diariusza ${ }^{6}$. Dzieło to nosi tytuł Itinerario overo relation in forma di Diario di tutte le cose occorse specialmente in materia di cerimonie tano nel viaggio come in Cracovia et in Versovia all Illustrissimo et Reveredissimo Henrico Cardinal Caetano Legato Apostolico al Serenissimo Re et Regno di Polonia i jest znane z kilku kopii powstałych na przełomie XVI i XVII w. ${ }^{7}$ Jeden z tych manuskryptów, przygotowany dla kardynała Alfonsa Gesualdo, trafił w czasie wojen napoleońskich, za pośrednictwem generała Henryka Dąbrowskiego, do Polski. Najpierw był przechowywany w Archiwum Potockich w Wilanowie, a obecnie znajduje się w Archiwum Głównym Akt Dawnych w Warszawie ${ }^{8}$. W Diariuszu Mucantego znaleźć można liczne odniesienia do kwestii tureckiej w kontekście pertraktacji, prowadzonych latem $1596 \mathrm{r}$. w Krakowie, w sprawie zawiązania Ligi Świętej z udziałem Rzeczypospolitej.

Przebieg tych pertraktacji został ponadto zreferowany w osobnym traktacie, sporządzonym przez jednego z nepotów towarzyszących kardynałowi Caetaniemu'. We współczesnym opisie tego źródła, w Bibliotece Watykańskiej, przypisuje się autorstwo urodzonemu w 1572 r. Benedetto Caetaniemu. Wydaje się to jednak mało prawdopodobne, ponieważ Benedetto Caetani, patrycjusz neapolitański i opat klasztoru Santa Maria w Faenzy, nie był wówczas w Polsce. Towarzyszył on swojemu stryjowi (młodszemu bratu Enrica) Camillo Caetaniemu, od 20 września 1592 r. nuncjuszowi w Hiszpanii, w jego misji na Półwyspie Iberyjskim. W czasie pełnienia tej funkcji wspomniany Benedetto zmarł jesienią

Nunz. Diverse 273; AAV Fondo Pio 114; AAV Fondo Pio 115; Bibliotheca Apostolica Vaticana (dalej BAV), Mss. Chigi M.I.12; Archivio Caetani Roma, ms 62/57; Biblioteca Casanatense Roma, ms. 1562; Biblioteca Casanatense Roma, ms. 1563; Biblioteca Casanatense Roma, ms. 1565.

${ }^{5}$ B. Vanozzi, Lettere miscellanee, nelle quali si contengono molte Azioni importantissime della Legazione di Monsignore Illustrissimo Caetano Legato a Latere di Nostro Signore in Polonia, Venetia 1606, s. 347-513.

${ }^{6}$ Jak wykazał to przed laty Jan Władysław Woś, spod pióra Gian Paola Mucantego wyszły jednocześnie cztery nieznacznie się od siebie różniące wersje dedykowane Enrico Caetaniemu, Edoardo Farnesemu, Alfonsowi Gesualdo i Pietro Aldobrandiniemu. Autor pragnął pozyskać przychylność tych dostojników, od których zależała jego własna kariera kościelna, J. W. Woś, Itinerario in Polonia del 1596 di Giovanni Mucante cerimoniere pontificio, Roma 1981, s. 17-18.

${ }^{7}$ Kopie Diariusza Giovanni Paolo Mucantego przechowywane są m.in. w kilku archiwach i bibliotekach rzymskich: BAV, Barb. lat. 5189; BAV, Ottob. lat. 2623; BAV, Barb. lat. 5262; Archivio Caetani Roma, ms. 59/78; Archivio Caetani Roma, ms. 60/792; Archivio di Stato di Roma, Fondo „Cartari-Febei” busta 69.

${ }^{8}$ Archiwum Główne Akt Dawnych, ms. 159; na potrzeby niniejszego artykułu korzystałem z liczącej 387 kart kopii Diariusza, przechowywanej w Bibliotece Apostolskiej Watykańskiej, w zbiorze Barberini Latini pod nr. 5189. Fragment odnoszący się do pierwszego okresu pobytu w Krakowie kardynała Enrico Caetaniego od połowy czerwca do 12 sierpnia 1596 r. wydał drukiem przed laty Jan Władysław Woś, w cytowanej wyżej jego pracy pt. Itinerario in Polonia del 1596 di Giovanni Mucante cerimoniere pontificio, s. 31-66.

${ }^{9}$ Kopia tego traktatu zachowała się w rękopisie BAV, Urb. lat. 859, f. 339-356. 
1596 r., przypuszczalnie w Madrycie ${ }^{10}$. Najprawdopodobniej autorem wspomnianego wyżej tekstu był Bonifazio, nepot kardynała Enrico Caetaniego, który pełnił w czasie legacji do Polski funkcję jego zaufanego doradcy i pomocnika ${ }^{11}$.

Misja dyplomatyczne kardynała Caetaniego miała ścisły związek z toczącą się od 1593 r. nową wojną pomiędzy monarchią habsburską a Imperium Osmańskim ${ }^{12}$. Wybuch tej wojny ze szczególnym niepokojem przyjęto na dworze papieskim. Dla uważnych obserwatorów było bowiem jasne, że siły samej tylko monarchii habsburskiej są za słabe, aby powstrzymać armię padyszacha. Służby dyplomatyczne donosiły też papieżowi, że coraz poważniejszym problemem staje się dziwne zachowanie Rudolfa II. Władca ten zaczął spędzać czas w towarzystwie astrologów i alchemików, prawie zupełnie zapominając o sprawach państwowych ${ }^{13}$. Tymczasem sytuacja na froncie wojennym wymagała podejmowania szybkich decyzji. Nad Tybrem obawiano się, że po ewentualnym upadku Austrii nic nie stanie na przeszkodzie, aby wojska tureckie wkroczyły do Italii i zajęły Rzym. Zagrożenie było realne, bo austriaccy Habsburgowie w tym konflikcie byli osamotnieni. Cesarz od dawna już nie mógł liczyć na pomoc krajów protestanckich, ale obecnie uchylały się również od jej udzielenia, aktywne na tym polu wcześniej, osłabione wojnami Hiszpania i Wenecja ${ }^{14}$. W tej sytuacji papież postanowił zaapelować o pomoc do Rzeczypospolitej. Sprawa nie była prosta, bo relacje między obydwoma państwami od dawna pozostawały w napięciu, które utrwalała odwieczna niechęć szlachty polskiej do Habsburgów. Ostatnio podgrzał ją jeszcze upór arcyksięcia Maksymiliana, używającego tytułu króla polskiego, z którego nie zrezygnował po przegranej kilka lat wcześniej rywalizacji z Zygmuntem III Wazą o polski tron ${ }^{15}$. Klemens VIII i jego kurialni urzędnicy dostrzegali jednak szansę na doprowadzenie pomiędzy obydwoma katolickimi monarchiami do porozumienia i zgody. Nadzieją napawało ich to, że nad Wisłą coraz bardziej zdawano sobie sprawę z konsekwencji niepowstrzymanej ekspansji tureckiej w Europie Środkowej. Dowodem na to była popularność w Polsce pod koniec XVI w. turcyków - pism o treści antyislamskiej i antytureckiej ${ }^{16}$. Ich autorzy przedstawiali czytelnikom skalę zagrożenia, nawoływali do porzucenia kłótni i sporów, i zjednoczenia wszystkich sił w celu storpedowania

${ }^{10}$ Smutna wiadomość o śmierci Benedetta dotarła do kardynała Caetaniego 17 listopada 1596 r., zaraz po tym jak kardynał wrócił do Krakowa z pierwszego swojego pobytu w Warszawie. BAV, Barb. lat. 5189, f. $157 \mathrm{v}$.

${ }^{11}$ Zob. hasło Caetani Bonifazio, [w:] Dizionario Biografico degli Italiani, vol. 16, Roma 1973, s. 135-136.

${ }^{12}$ W historiografii światowej została nazwana „Długą Wojną”, ponieważ zakończyła się dopiero jesienią 1606 r. Zob. C. Finkel, The Administration of Warfare. The Ottoman Military Campaigns in Hungary (1593-1606), Wien 1988; J. P. Niederkorn, Die europäischen Mächte und der ,L Lange Türkenkrieg” Kaiser Rudolfs II. (15931606), Wien 1993; K. M. Setton, Venice, Austria and Turks in the Seventeenth Century, Philadelphia 1991, s. 6 i n.; M. Jačov, Europa i Osmanie w okresie Lig Świętych. Polska między Wschodem a Zachodem, Kraków 2003, s. $45-79$.

${ }^{13}$ P. Marshall, The Mercurial Emperor. The Magic Circle of Rudolf II in Renaissance Prague, London 2007, s. $185 \mathrm{i} \mathrm{n.}$

${ }^{14}$ Wrogie działania przeciwko cesarstwu prowadziła w tamtym czasie Francja, która podburzała protestantów oraz w jawny sposób współpracowała z dworem sułtańskim. J. Sas, Układy o Lige przeciw Turkom za Zygmunta III, „Przegląd Powszechny”, 63, 1899, s. 57-58.

${ }^{15}$ Ibidem, s. 198-200.

${ }^{16}$ Ibidem, s. 68-69. Na temat samych turcyków - tekstów historycznych i literackich o tematyce tureckiej w epoce nowożytnej zob. C. Gölner, Turcica - Die europäischen Türkendrucke des XVI. Jahrhunderts, t. 1, Bucaresti 1961, t. 2 Baden-Baden 1968, t. 3 Baden-Baden 1978; J. Tazbir, Polska przedmurzem Europy, Warszawa 2004 , s. 55-56. 
muzułmańskich najeźdźców ${ }^{17}$. Jednym z tych autorów był biskup kijowski Józef Wereszczyński, który w swoim ekscytarzu wojennym z 1592 r. ostrzegał przed wzrastającym niebezpieczeństwem ze strony muzułmanów, poczynających sobie coraz bardziej agresywnie $^{18}$. W kolejnym swoim tekście doradzał szybkie założenie szkoły rycerskiej, przygotowującej młodzież do walki z muzułmanami, i zagospodarowanie pustoszonych przez nich południowych i wschodnich ziem Rzeczypospolitej ${ }^{19}$. Czytano też turcyki Krzysztofa Warszewickiego, pisarza politycznego i dyplomaty, wydane w Krakowie w 1595 r. pod zbiorczym tytułem Turcicae quatuordecim. Teksty te zapowiadały nieuchronność konfrontacji między kulturą i cywilizacją chrześcijańską a islamem. Warszewicki twierdził, że turecka religia, odrzucająca osobę Chrystusa jako Boga i dawcy wiecznego zbawienia, jest główną przeszkodą w zawarciu z nimi jakiegokolwiek porozumienia. Jego zdaniem, islam stanowił śmiertelne zagrożenie dla cywilizacji chrześcijańskiej i wszystkie państwa - w tym Polska - powinny jak najszybciej zewrzeć szeregi i utworzyć antyturecką koalicjęę

Powyższe teksty odzwierciedlają rzeczywistą atmosferę tamtych czasów. W opinii kurialnych urzędników stwarzała ona szansę na to, że państwo polsko-litewskie - zachowujące od kilkudziesięciu lat neutralność w stosunkach z Turcją - zmieni swoją dotychczasową politykę. Po upadku Węgier Królestwo Polskie zaczęło wyrastać na prawdziwe przedmurze chrześcijaństwa w regionie środkowej Europy - realną siłę mogącą przeszkodzić Turkom w dalszych podbojach ${ }^{21}$. Kierownicy polityki polskiej zaczęli uświadamiać sobie powolne zbliżanie się tureckich armii do granic Królestwa i to, że okropieństwa, które dotknęły Słowian Południowych, Wołochów i Węgrów, mogą stać się niedługo udziałem także Polaków ${ }^{22}$. Na główny teren sporu pomiędzy Polską a Turcją wyrosła Mołdawia, uznawana przez kierowników polityki polskiej za jej dawne lenno ${ }^{23}$. Na tym terenie swoje

${ }^{17} \mathrm{O}$ wzroście poczucia zagrożenia w Europie nowożytnej ze strony Turków osmańskich zob. K. M. Setton, Western Hostility to Islam and Prophecies of Turkish Doom, Philadelphia 1992; The Turk and islam in the Western Eye (1450-1750), ed. J. G. Harper, London-New York 2017.

${ }^{18}$ J. Wereszczyński, Ekscytarz ... do podniesienia wojny świętej przeciwko Turkom i Tatarom, jako głównym nieprzyjacielom wszystkiego chrześcijaństwa, Kraków 1592.

${ }_{19}$ J. Wereszyczyński, Publika... tak ze strony fundowania szkoły rycerskiej synom koronnym na Ukrainie, jako też Krzyżakom według reguły maltańskiej, Kraków 1594. Autor ten głosił również potrzebę włączenia Moskwy do antymuzułmańskiego sojuszu. Idem, Pobudka na Jego cesarska Miłość Wszystkiego Chrześcijaństwa, jako też na Jego K.M. Króla Polskiego. Tudzież też na Jaśnie Oświeconego Kniazia Wielkiego Moskiewskiego, do podniesienia wojny świętej spólnq ręka przeciw Turkom i Tatarom, Wilno 1594.

${ }^{20}$ To obszerne, liczące 314 stron dzieło było kompilacją jego Turcicae tres, napisanego i opublikowanego podczas wygnania w Pradze w 1589 r., wraz z jedenastoma nowymi antytureckimi tekstami. Zob. N. Frejek, Krzysztof Warszewicki, [w:] Christian-Muslim Relations. A Bibliographical History, t. 8, Leiden-Boston 2016, s. 692-696. Więcej na temat polskich turcyków tamtej doby zob. W. Pyłypenko, W obliczu wroga. Polska literatura antyturecka od połowy XV do połowy XVII wieku, Oświęcim 2016; J. Sikorski, Problematyka walki z Turkami w polskiej literaturze wojskowej i politycznej XVI-XVII w., „Studia i Materiały do Historii Wojskowości”, 27, 1984, s. 147-156; L. Jarmiński, La Polonia di fronte ai tentativi per una lega antiturca sotto Clemente VIII, „Odrodzenie i Reformacja w Polsce”, 39, 1995, s. 109.

${ }^{21}$ J. Tazbir, Polskie przedmurze chrześcijańskiej Europy. Mity a rzeczywistość historyczna, Warszawa 1987; Idem, Najnowsze spory o Polskie przedmurze 1939-1992, „Kwartalnik Historyczny”, 4 (1993), s. 251-264.

${ }^{22}$ J. János Varga, Europa und „Die Vormauer des Christentums”, [w:] Europa und die Türken in der Renaissance, red. B. Guthmüller, W. Kühlmann, Tübingen 2000, s. 62; J. Tazbir, Wegry jako symbol i przestroga w literaturze staropolskiej, „Odrodzenie i Reformacja w Polsce”, 36 (1991), s. 154-155.

${ }^{23}$ W XVI w. Mołdawię, Wołoszczyznę i Siedmiogród postrzegano w Polsce jako państwa buforowe. Próba rozciągnięcia kontroli nad tymi krajami oznaczała przesunięcie linii obrony przed zagrożeniem tureckim na linię Dunaju. Z. Spieralski, Awantury mołdawskie, Warszawa 1967, s. 142. 
polityczne interesy mieli poza Turcją również Habsburgowie, którzy nie ukrywali chęci rozciągnięcia swojej kontroli nad całym basenem środkowego Dunaju. Ideę zlikwidowania islamskiego zagrożenia bez współdziałania z dworem cesarskim zaszczepił w Polsce Stefan Batory, a po jego przedwczesnej śmierci myśl tę podjął i starał się kontynuować kanclerz wielki koronny Jan Zamoyski ${ }^{24}$.

Najważniejszym zadaniem udającego się do Polski kardynała Caetaniego było przekonanie kierowników jej polityki do zgody na udział w montowanej przez papieża Lidze Świętej, skierowanej przeciwko Turkom. Jak już wyżej wspomniano, główną przeszkodą na jej drodze był niezrozumiały dla wielu upór arcyksięcia Maksymiliana Habsburga, używającego tytułu króla polskiego wbrew podpisanemu w 1589 r. traktatowi bytomsko-będzińskiemu. Stawiał on ponadto coraz to nowe warunki jego zrzeczenia się. Zygmunt III Waza nie zdążył zdobyć sobie jeszcze poparcia wszystkich sił politycznych w kraju i zjednoczyć poddanych wokół idei wojny z Turcją. Pozostający jednak pod dużym wpływem jezuitów monarcha nie miał nic przeciwko współpracy z cesarzem ${ }^{25}$. Propozycje papieskie wspierał przy tym usilnie biskup krakowski kardynał Jerzy Radziwiłł i grupa senatorów z kasztelanem krakowskim Januszem Ostrogskim na czele. Na przełomie lat 1595/1596 wydawało się, że nawet stojący do tej pory po przeciwnej stronie zaciekły przeciwnik polityki Habsburgów, hetman Jan Zamoyski zmienił zdanie. Misja kardynała Caetaniego rozpoczynała się więc w korzystniejszych nieco dla sprawy wojny z Turcją okolicznościach politycznych i uwarunkowaniach międzynarodowych ${ }^{26}$.

Giovanni Paolo Mucante zanotował w swoim Diariuszu wiele szczegółów związanych z pobytem kardynała Caetaniego w Krakowie. Papieskiego ceremoniarza interesowały nie tylko uroczystości religijne, ale również życie codzienne mieszkańców polskiej stolicy, wygląd miasta i jego charakter. Autor nie omieszkał też zamieścić w swojej relacji własnych komentarzy odnośnie do spraw politycznych, również tych dotyczących pertraktacji w sprawie powołania Ligi Świętej. Jak zanotował Mucante, uroczysty wjazd kardynała Enrica Caetaniego do Krakowa odbył się w niedzielę, 16 czerwca 1596 r. Przyglądały mu się nieprzeliczone thumy szlachty, mieszczan i ludu ${ }^{27}$. Papieskiego legata powitał krakowski biskup, kardynał Jerzy Radziwiłł, pełniący w zastępstwie króla Zygmunta III Wazy honory gospodarza w stolicy ${ }^{28}$. Następnie wspaniała kawalkada przybyszy z Italii - wraz z odświętnie wystrojonymi oddziałami wojsk możnowładców i szlachty - przejechała przez centrum miasta, zdążając do wawelskiej katedry. Po przybyciu na miejsce odśpiewano Te Deum laudamus i odprawiono stosowne modlitwy, po których kardynał Caetani odprowa-

${ }^{24}$ Z. Spieralski, Awantury mołdawskie, s. 142-149. Por. J. Besala, Stefan Batory, Warszawa 1992, s. $462-468$. Istnieje też opinia, że Stefan Batory nie planował żadnej akcji antytureckiej, zob. K. Dopierała, Stosunki dyplomatyczne Polski z Turcja za Stefana Batorego, Warszawa 1986, s. 156.

${ }^{25}$ L. Jarmiński, Trudne starania o wystanie posła Zygmunta III Wazy z obediencja do papieża Klemensa VIII, „Odrodzenie i Reformacja w Polsce”, 61, 1997, s. 169-174.

${ }^{26}$ J. Sas, Układy o Ligę przeciw Turkom za Zygmunta III, s. 190-211. Wzrost poparcia dla planów stworzenia Ligi sygnalizował Kurii Rzymskiej w tamtym czasie również nuncjusz papieski w Polsce, Malaspina; zob. L. Jarmiński, La Polonia di fronte ai tentativi per una lega antiturca sotto Clemente VIII, s. 111-112.

${ }^{27}$ BAV, Barb. lat. 5189, f. 33r.; J. U. Niemcewicz, Zbiór pamiętników historycznych o dawnej Polszcze, t. 2 , Warszawa 1822, s. 98-99; J. W. Woś, Itinerario in Polonia del 1596 di Giovanni Mucante cerimoniere pontificio, s. 33.

${ }^{28}$ Mucante określił go w swoim Diariuszu mianem ,,pastor buono et vigilante di quella città”. BAV, Barb. lat. 5189, f. 40v-41r.; J. W. Woś, Itinerario in Polonia del 1596 di Giovanni Mucante cerimoniere pontificio, s. 40. 
dzony został do pałacu biskupiego, położonego naprzeciw kościoła Franciszkanów. Miejsce to zostało wyznaczone na jego rezydencję na cały okres pobytu w Krakowie ${ }^{29}$.

Kardynał Caetani nie zaniedbywał spraw należących do głównych zadań jego misji, o czym świadczy niezwykle duża liczba wysyłanej korespondencji dyplomatycznej i jej bogata treść. Częstym gościem w jego rezydencji był kardynał Jerzy Radziwiłł, z którym układał strategię działania na zjazd w sprawie organizacji antytureckiej Ligi Świętej. Krakowski biskup był gorącym zwolennikiem idei ofensywnej wojny z Turcją. Papieski legat nie był przekonany co do podobnych intencji dworu cesarskiego w Pradze. Niepokoiła go szczególnie gnuśność Rudolfa II i jego otoczenia w sprawach niecierpiących zwłoki. Kardynał Caetani napominał listownie nuncjusza apostolskiego w Pradze, aby przypomniał cesarzowi o potrzebie przysłania na pertraktacje do Polski w sprawach tureckich swoich przedstawicieli. W końcu 4 lipca Rudolf II powiadomił legata o zgodzie na ich wyjazd, żądając przy tym, aby obrady toczyły się w Krakowie ${ }^{30}$.

Jak podał w swoim Diariuszu Giovanni Paolo Mucante, w związku z zapowiedzianym kongresem, 12 lipca 1596 r. pojawił się w Krakowie najpierw nuncjusz apostolski w Polsce, biskup San Severo Germanico Malaspina ${ }^{31}$. Kilkanaście dni później dotarł tam również nadzwyczajny nuncjusz, biskup Caserty Benedetto Mandina ${ }^{32}$. Komisarze cesarscy z biskupem wrocławskim Andreasem Jerinem na czele przybyli pod Wawel dopiero na początku sierpnia. Oczekiwało tu na nich dwudziestu przedstawicieli polskiego parlamentu, wydelegowanych zarówno przez senat, jak i sejm. Rozpoczęcie wspólnych obrad poprzedziła uroczysta Msza św., którą odprawiono w środę 7 sierpnia w kościele Mariackim przy Rynku. Jak zanotował Giovanni Paolo Mucante, liturgii, w wypełnionej po brzegi świątyni, w obecności cesarskich komisarzy i polskiej delegacji, przewodniczył kardynał Jerzy Radziwiłł. Papieskiemu legatowi przygotowano w prawej części prezbiterium tron pod baldachimem, a w stallach po obu stronach zasiedli w odpowiednim porządku dwaj nuncjusze apostolscy oraz komisarze cesarscy i polscy dostojnicy. Giovanni Paolo Mucante zauważył, że spośród wszystkich tych osób pierwszeństwo przypadło nuncjuszowi Malaspinie, jako pełniącemu urząd nuncjusza rezydenta. Msza święta sprawowana była zgodnie z tradycyjnym zwyczajem polskim, do którego należała procesja z Najświętszym Sakramentem wokół naw kościoła. Kardynała Caetaniego poproszono jedynie na końcu ceremonii o udzielenie uroczystego błogosławieństwa wszystkim zgromadzonym. Mucante podał, że papieski legat został następnie odprowadzony do wyjścia przez biskupów stojących na czele delegacji cesarskiej ${ }^{33}$.

${ }^{29}$ BAV, Barb. lat. 5189, f. 33v-36r; J. U. Niemcewicz, Zbiór pamiętników historycznych o dawnej Polszcze, t. 2, s. 99-100; J. W. Woś, Itinerario in Polonia del 1596 di Giovanni Mucante cerimoniere pontificio, s. 33-35.

${ }^{30}$ J. Sas, Układy o Lige przeciw Turkom za Zygmunta III, s. 352. Kardynał Caetani z wielką radością wspominał o wyborze przez cesarza Krakowa na miejsce obrad w liście z 5 lipca 1596 r. do Sekretarza Stanu kardynała Cinzio Passeri Aldobrandiniego. Podkreślił przy tym szczególnie dogodne położenie miasta oraz wysoki poziom jego infrastruktury: „,...] Finalmente venne dalla corte cesarea la dichiaratione del luogo per la tratttatione, e sarà questa Città di Cracovia, che doverà facilitar la venuta di molti di questi deputati per la commodità, che s'haverà qui più, che altrove". Biblioteca Casanatense Roma, ms. 1563, f. 78v.

${ }^{31}$ BAV, Barb. lat. 5189, f. 56v; J. W. Woś, Itinerario in Polonia del 1596 di Giovanni Mucante cerimoniere pontificio, s. 55.

${ }^{32}$ BAV, Barb. lat. 5189, f. 59v; J. W. Woś, Itinerario in Polonia del 1596 di Giovanni Mucante cerimoniere pontificio, s. 58 .

${ }^{33}$ BAV, Barb. lat. 5189, f. 62r-66r; J. W. Woś, Itinerario in Polonia del 1596 di Giovanni Mucante cerimoniere pontificio, s. 61-63. 
Właściwe obrady obydwu delegacji zaczęły się następnego dnia w specjalnie przygotowanej dużej sali pałacu biskupiego, gdzie rezydował kardynał Caetani. Jak zanotował Mucante, było to przestronne miejsce, w którym zazwyczaj spożywano posiłki ${ }^{34}$. U jej szczytu ustawiono dla kardynała legata reprezentacyjny tron z baldachimem, nakryty czerwonym aksamitem. W jego pobliżu, z prawej strony stało nieco mniejsze krzesło, przeznaczone dla kardynała Jerzego Radziwiłła. Po przeciwnej stronie, w podobnej odległości, ustawiono natomiast osiem krzeseł, w tym dwa dla nuncjuszy apostolskich, a pozostałe sześć dla komisarzy cesarskich. Symetrycznie naprzeciw nich ustawionych zostało siedem krzeseł dla najznaczniejszych senatorów strony polskiej. Zaplanowano to tak, aby naprzeciwlegle biskupa Malaspiny siedział biskup przemyski Wawrzyniec Goślicki ${ }^{35}$, obok niego wojewoda krakowski Mikołaj Firlej ${ }^{36}$, a dalej: wojewoda poznański Hieronim Gostomski ${ }^{37}$, wojewoda łęczycki Stanisław Miński ${ }^{38}$, marszałek wielki koronny Mikołaj Zebrzydowski ${ }^{39}$, wielki kanclerz litewski Lew Sapieha ${ }^{40}$ i podskarbi wielki litewski Dymitr Chalecki ${ }^{41}$. Przedstawiciele izby poselskiej i niżsi rangą urzędnicy zasiedli na specjalnych ławach ustawionych pod ścianami. Jak zauważył Mucante, wszystkie krzesła i ławy ustawiono tak, aby tworzyły duży kwadrat, przypominając sposób, w jaki rozkładano miejsca w czasie audiencji prywatnych u papieża z udziałem kardynałów. Drzwi do sali były otwarte i w przyległym korytarzu cisnęli się - próbując wszystko zobaczyć i usłyszeć - członkowie kardynalskich i biskupich familii oraz dworzanie i sekretarze dostojników świeckich. Wśród nich był również autor analizowanego Diariusza $a^{42}$.

Kardynał Enrico Caetani, rozpoczynając obrady, poprosił najpierw osobistego sekretarza Bonifazia Vanozziego o odczytanie wydanej dla niego papieskiej bulli nominacyjnej. Treści tego dokumentu zebrani wysłuchali w wielkim skupieniu. Ceremoniarz papieski zwrócił uwagę na to, że za każdym razem, kiedy Vanozzi wypowiadał imię Ojca św. Klemensa VIII, zebrani wstawali i z uszanowaniem zdejmowali nakrycia głowy. Papież nawiązywał w tej bulli do własnego zaangażowania w obronę religii i cywilizacji chrześcijańskiej przed wzrastającym zagrożeniem ze strony osmańskiej Turcji. Jego dotychczasowe działania nie ograniczały się wyłącznie do deklaracji, ale miały realny wymiar - w postaci ludzi i pieniędzy wysyłanych na pomoc cesarzowi i księciu siedmiogrodzkiemu Zygmuntowi. Wszystkie te posunięcia okazały się jednak niewystarczające do pokonania Turków. Po-

${ }^{34}$ BAV, Barb. lat. 5189, f. 66r; J. W. Woś, Itinerario in Polonia del 1596 di Giovanni Mucante cerimoniere pontificio, s. 63 .

${ }^{35}$ D. Maniewska, Goślicki Wawrzyniec, [w:] Polski Słownik Biograficzny, t. 8, Wrocław 1959, s. 379-382; A. Stępkowski, Wawrzyniec Grzymała Goślicki - życie i działalność, „Prawo Kanoniczne”, 42/1-2, 1999, s. 225-241; O senatorze doskonatym studia. Prace upamiętniajace postać i twórczość Wawrzyńca Goślickiego, red. A. Stępkowski, Warszawa 2009.

${ }^{36}$ K. Lepszy, Mikołaj Firlej, [w:] Polski Stownik Biograficzny, t. 7, Kraków 1948, s. 12-15.

${ }^{37}$ Wielkopolski Stownik Biograficzny, red. A. Gąsiorowski, Jerzy Topolski, Warszawa-Poznań 1981, s. $215-216$.

${ }^{38}$ S. Gruszecki, Miński Stanisław, [w:] Polski Stownik Biograficzny, t. 21, Wrocław-Warszawa-Kraków 1976, s. 320-322.

${ }^{39}$ L. Wierzbicki, Senatorowie koronni na sejmach Rzeczypospolitej, Warszawa 2017, s. 181.

${ }^{40}$ H. Lulewicz, Sapieha Lew, [w:] Polski Słownik Biograficzny, t. 35, Warszawa-Kraków 1994, s. $84-105$.

${ }^{41}$ O. Halecki, Dymitr Chalecki, [w:] Polski Słownik Biograficzny, t. 3, Kraków 1937, s. 247-249.

${ }^{42}$ BAV, Barb. lat. 5189, f. 66r-66v; J. W. Woś, Itinerario in Polonia del 1596 di Giovanni Mucante cerimoniere pontificio, s. 63-64. 
trzebna była realna siła - taka, jaką dysponowała Rzeczypospolita, do wzmocnienia strony chrześcijan. Dlatego też papież wzywał Polaków, by przystąpili do organizowanej przez Stolicę Apostolską Ligi Świętej. Powierzając kardynałowi Enrico Caetaniemu godność legata a latere, Klemens VIII oczekiwał, iż będzie on przez wszystkich postrzegany jako prawdziwy jego zastępca i że jego decyzje będą respektowane ${ }^{43}$.

Po odczytaniu tej bulli głos zabrał kardynał Caetani - jak zaznaczył Mucante - używając pięknej i eleganckiej łaciny. Legat przekonywał, że gdyby papież Klemens VIII nie miał pewności, iż Polacy pragną szczerze brać udział w negocjacjach na temat wojny z Turcją, nie marnowałby pieniędzy i nie wysyłałby do nich swoich przedstawicieli. Poznał on jednak Polaków i wie, jak mocno przywiązani są do katolickiej wiary. Świadczy o tym choćby rewerencja, jaką okazują zawsze Stolicy Apostolskiej i osobiście papieżowi. Z tego też powodu Klemens VIII ma nadzieję, że nie uchylą się od udzielenia pomocy w walce z największymi nieprzyjaciółmi chrześcijan. Legat mówił dalej, że papież, nie mogąc osobiście przybyć do Polski, świadomie wybrał go spośród kardynałów i polecił mu realizację niezwykle trudnej, ale i zaszczytnej misji. On sam nie potrafił odmówić, bo prośba papieża dotyczyła spraw najwyższej wagi, dla których był gotów złożyć nawet ofiarę krwi. Legat zapewnił zebranych, że zadania, jakie przed nim postawiono, ma zamiar spełnić rzetelnie, kierując się sprawiedliwością oraz szacunkiem okazywanym całemu narodowi polskiemu, ale i każdemu z osobna. I choć - jak powiedział - w kolegium kardynalskim są różne poglądy na przedmiotowe sprawy, jego pełnomocnictwa wykluczają jakąkolwiek podległość i nikt nie powinien mieć obawy o jego stronniczość. Najżarliwszym życzeniem papieża było to, aby panowie polscy zgodzili się na połączenie swoich sił z cesarskimi w celu wspólnej walki z Turkami. Kardynał nie ukrywał przed zebranymi osobistego przeświadczenia, że rozpoczęta w Krakowie debata na ten temat zakończy się właśnie takim postanowieniem. Jak obiecywał, Stolica Apostolska ma zamiar wesprzeć te działania wszelkimi środkami, jakimi dysponuje. Legat zapewnił zebranych, że papież uczyni wszystko, aby do tego sojuszu dołączyły także pozostałe państwa chrześcijańskie. Na koniec legat wezwał obydwie układające się strony do daleko posuniętego kompromisu. Jego zdaniem, wszystkie warunki i propozycje powinny zostać omówione i rozstrzygnięte na rozpoczynającym obrady krakowskim kongresie ${ }^{44}$.

Gdy kardynał legat skończył, głos zabrał w imieniu cesarza biskup wrocławski Jerin. Przemawiając również po łacinie, podziękował najpierw papieżowi i reprezentującemu go legatowi za zorganizowanie tego zjazdu. Biskup zapewniał zebranych, że cesarz pragnie połączyć swoje wojska z siłami króla polskiego w celu wspólnego uderzenia na Turków. W związku z rozpoczętymi pertraktacjami pragnął jedynie zaznaczyć, że nie mógł zobowiązać się do składania obietnic, których w przyszłości nie mógłby dotrzymać. W imieniu strony polskiej wystąpił natomiast biskup przemyski Wawrzyniec Goślicki. Nie ukrywał on swojego rozczarowania oszczerstwami rzucanymi w ostatnim czasie na arenie międzynarodowej na Królestwo Polskie, jakoby współdziałało z Turkami. Tymczasem - jak twierdził - nie kto inny, ale Polacy, nie szczędząc własnej krwi, bronią Węgier i ziem cesarskich

${ }^{43}$ Biblioteca Casanatense Roma, ms. 1565, f. 3r-22v; BAV, Barb. lat. 5189, f. 66v-67r; J. W. Woś, Itinerario in Polonia del 1596 di Giovanni Mucante cerimoniere pontificio, s. 64.

${ }^{44}$ BAV, Barb. lat. 5189, f. 67r-68r; J. W. Woś, Itinerario in Polonia del 1596 di Giovanni Mucante cerimoniere pontificio, s. 64-65. 
przed najazdami sprzymierzonych z sułtanem Tatarów. Co do Ligi Świętej, to Polska nigdy nie uchylała się od wejścia do niej. Jednak jego zdaniem, uzgodnienie wszystkich warunków współpracy w jej ramach wymagało spokojnego omówienia wielu spraw, na których zależało zarówno papieżowi i cesarzowi, jak i stronie polskiej. Po wysłuchaniu tych głosów kardynał Caetani zapewnił zebranych, że jego rezydencja stoi otworem przed kolejnymi sesjami rozmów i pertraktacji. Następne spotkanie wyznaczył na poniedziałek 11 sierpnia, ponieważ, jak stwierdził, w sobotę wypadała uroczystość Św. Wawrzyńca, a w niedzielę nie powinno się prowadzić dysput politycznych. Ponadto, według niego, Polacy powinni mieć czas, aby uzgodnić między sobą swoje żądania ${ }^{45}$.

Na tym zakończyła się relacja Giovanniego Paola Mucantego odnośnie do pierwszego dnia obrad w sprawie powstania Ligi Świętej w Krakowie w sierpniu 1596 r. Pertraktacje te trwały jeszcze przez prawie miesiąc $\mathrm{i}$ wbrew nadziejom legata nie zakończyły się pozytywną konkluzją. Rozczarowanie kardynała Caetaniego było tak duże, że w pierwszej chwili zamierzał natychmiast wracać do Wiecznego Miasta. Papież był jednak innego zdania i nakazał mu pozostać jeszcze w Polsce, aby i w sejmie, i na dworze królewskim szukać wsparcia dla tego projektu. Razem z nim pozostał również Giovanni Paolo Mucante, wzbogacając swój Diariusz o nowe relacje i opisy. Choć papieskiego ceremoniarza bardziej interesowały uroczystości religijne i życie codzienne mieszkańców niż polityczne targi i atmosfera dysput w sprawach projektów wojennych, to pozostawione przez niego dzieło należy uznać za niezwykle cenne. Przytoczone wyżej fragmenty z Diariusza Giovanniego Paola Mucante są przykładem ważnych uzupełnień na temat zdarzeń znanych z innych, przede wszystkim dyplomatycznych, źródeł.

\section{Bibliografia}

Źródła:

Acta Nuntiaturae Polonae, t. XV/1, wyd. L. Jarmiński, Kraków 2000.

Archivio Caetani Roma, ms 62/57.

Archivum Apostolicum Vaticanum: Segr. Stato, Nunz. Diverse 273; Fondo Pio 114; Fondo Pio 115.

Bibliotheca Apostolica Vaticana, Barb. lat. 5189.

Bibliotheca Apostolica Vaticana, Mss. Chigi M.I.12

Bibliotheca Apostolica Vaticana, Urb. lat. 859, f. 339-356.

Biblioteca Casanatense Roma, ms. 1562.

Biblioteca Casanatense Roma, ms. 1563.

Biblioteca Casanatense Roma, ms. 1565.

Niemcewicz J. U., Zbiór pamiętników historycznych o dawnej Polszcze, t. 2, Warszawa 1822.

Vanozzi B., Lettere miscellanee, nelle quali si contengono molte Azioni importantissime della Legazione di Monsignore Illustrissimo Caetano Legato a Latere di Nostro Signore in Polonia, Venetia 1606.

Wereszczyński J., Ekscytarz... do podniesienia wojny świętej przeciwko Turkom i Tatarom, jako głównym nieprzyjacielom wszystkiego chrześcijaństwa, Kraków 1592.

${ }^{45}$ BAV, Barb. lat. 5189, f. 68r-69v; J. W. Woś, Itinerario in Polonia del 1596 di Giovanni Mucante cerimoniere pontificio, s. 65-66. 
Wereszczyński J., Pobudka na Jego cesarska Miłość Wszystkiego Chrześcijaństwa, jako też na Jego K.M. Króla Polskiego. Tudzież też na Jaśnie Oświeconego Kniazia Wielkiego Moskiewskiego, do podniesienia wojny świętej spólnq ręka przeciw Turkom i Tatarom, Wilno 1594.

Wereszczyński J., Publika ... tak ze strony fundowania szkoły rycerskiej synom koronnym na Ukrainie, jako też Krzyżakom wedtug reguty maltańskiej, Kraków 1594.

Literatura:

Barbiche B., De Dainville-Barbiche S., Les légats ,, a latere» en France et leurs facultés aux XVI et XVII siècles, „Archivum Historiae Pontificiae”, 23, 1985, s. 101-161.

Barbiche B., De Dainville-Barbiche S., Les légats a latere à l'epoque moderne et le personnel des légations, [w:] Bulla, Legatus, Nuntius. Études de diplomatique et de diplomatie pontificales (XIII ${ }^{e}-X V I I^{e}$ siècle), red. B. Barbiche, Paris 2007, s. 284-293.

Besala J., Stefan Batory, Warszawa 1992.

de Boûard M., Sixte-Quint, Henri IV et la Ligue. La légation du cardinal Caetani en France (15891590), „Revue des questions historiques”, 60, 1932, s. 59-140.

Caetani G., Domus Caietana. Storia documentata della famiglia Caetani. Il Cinquecento, t. 2, Sancasciano Val di Pesa 1933.

Dizionario Biografico degli Italiani, vol. 16, Roma 1973, s. 135-136.

Dopierała K., Stosunki dyplomatyczne Polski z Turcja za Stefana Batorego, Warszawa 1986.

Feldkamp M. F., La diplomazia pontificia, Milano 1998.

Finkel C., The Administration of Warfare. The Ottoman Military Campaigns in Hungary (1593-1606), Wien 1988.

Frejek N., Krzysztof Warszewicki, [w:] Christian-Muslim Relations. A Bibliographical History, t. 8, Leiden-Boston 2016.

de L'Epinois H., La légation du cardinal Caetani en France, „Revue des questions historiques”, 30, 1881, s. 60-525.

Gölner C., Turcica - Die europäischen Türkendrucke des XVI. Jahrhunderts, t. 1, Bucuresti 1961; t. 2, Baden-Baden 1968; t. 3, Baden-Baden 1978.

Gruszecki S., Miński Stanisław, [w:] Polski Stownik Biograficzny, t. 21, Wrocław-Warszawa-Kraków 1976, s. 320-322.

Halecki O., Dymitr Chalecki, [w:] Polski Stownik Biograficzny, t. 3, Kraków 1937, s. 247-249.

Jačov M., Europa i Osmanie w okresie Lig Świętych. Polska między Wschodem a Zachodem, Kraków 2003.

Jaitner K., Die Hauptinstruktionen Clemens 'VIII. für die Nuntien und Legaten an den europäischen Fürstenhofen (1592-1605), t. 1, Tübingen 1984.

Jarmiński L., La Polonia di fronte ai tentativi per una lega antiturca sotto Clemente VIII, „Odrodzenie i Reformacja w Polsce", 39, 1995, s. 107-116.

Jarmiński L., Trudne starania o wystanie posła Zygmunta III Wazy z obediencja do papieża Klemensa VIII, „Odrodzenie i Reformacja w Polsce”, 61, 1997, s. 169-174.

Lepszy K., Mikołaj Firlej, [w:] Polski Stownik Biograficzny, t. 7, Kraków 1948, s. 12-15.

Lulewicz H., Sapieha Lew, [w:] Polski Stownik Biograficzny, t. 35, Warszawa-Kraków 1994, s. 84-105.

Maniewska D., Goślicki Wawrzyniec, [w:] Polski Słownik Biograficzny, t. 8, Wrocław 1959, s. 379-382.

Manfroni C., La legazione del cardinal Caetani in Francia (1589-1590), „Rivista storica italiana”, 10, 1893, s. 90-270.

Marshall P., The Mercurial Emperor. The Magic Circle of Rudolf II in Renaissance Prague, London 2007.

Niederkorn J. P., Die europäischen Mächte und der „Lange Türkenkrieg” Kaiser Rudolfs II. (15931606), Wien 1993. 
O senatorze doskonalym studia. Prace upamiętniajace postać i twórczość Wawrzyńca Goślickiego, red. A. Stępkowski, Warszawa 2009.

Pyłypenko W., W obliczu wroga. Polska literatura antyturecka od połowy XV do połowy XVII wieku, Oświęcim 2016.

Sas J., Układy o Lige przeciw Turkom za Zygmunta III, „Przegląd Powszechny”, 63, 1899.

Setton K. M., Venice, Austria and Turks in the Seventeenth Century, Philadelphia 1991.

Setton K. M., Western Hostility to Islam and Prophecies of Turkish Doom, Philadelphia 1992.

Sikorski J., Problematyka walki z Turkami w polskiej literaturze wojskowej i politycznej XVI-XVII w., „Studia i Materiały do Historii Wojskowości”, 27, 1984, s. 147-156.

Spieralski Z., Awantury mołdawskie, Warszawa 1967.

Stępkowski A., Wawrzyniec Grzymała Goślicki-życie i działalność, „Prawo Kanoniczne”, 42/1-2, 1999, s. 225-241.

Tazbir J., Najnowsze spory o polskie przedmurze 1939-1992, „Kwartalnik Historyczny”, 4 (1993), s. 251-264.

Tazbir J., Polska przedmurzem Europy, Warszawa 2004.

Tazbir J., Polskie przedmurze chrześcijańskiej Europy. Mity a rzeczywistość historyczna, Warszawa 1987.

Tazbir J., Węgry jako symbol i przestroga w literaturze staropolskiej, „Odrodzenie i Reformacja w Polsce", 36 (1991), s. 147-161.

The Turk and islam in the Western Eye (1450-1750), ed. J. G. Harper, London-New York 2017.

Varga J. János, Europa und „,Die Vormauer des Christentums”, [w:] Europa und die Türken in der Renaissance, red. B. Guthmüller, W. Kühlmann, Tübingen 2000.

Wielkopolski Stownik Biograficzny, red. A. Gąsiorowski, Jerzy Topolski, Warszawa-Poznań 1981, s. $215-216$.

Wierzbicki L., Senatorowie koronni na sejmach Rzeczypospolitej, Warszawa 2017.

Woś J. W., Istruzione al cardinale Enrico Caetani per la sua missione in Polonia negli anni 1596-1597, „Annali della Scuola Normale Superiore di Pisa. Classe di Lettere e Filosofia”, Serie III, 6/3, 1976, s. 929-953.

Woś J. W., Itinerario in Polonia del 1596 di Giovanni Mucante cerimoniere pontificio, Roma 1981.

Janusz Smołucha, dr hab., profesor Akademii Ignatianum w Krakowie. Historyk i kulturoznawca, autor wielu prac z zakresu dyplomacji papieskiej oraz stosunków Polski ze Stolicą Apotolską w średniowieczu i epoce nowożytnej. Jego zainteresowania badawcze koncentrują się wokół przemian kulturowych w krajach Europy Środkowej oraz wspólnej obrony państw tego regionu przed zagrożeniem ze strony islamu.

ORCID: 0000-0003-2633-7093 